\section{VIDA Adrienn}

\section{A TERMÉSZETTUDOMÁNYOS TÁRGYAK ÉS A KUTATÓI PÁLYA IRÁNTI ÉRDEKLŐDÉS VIZSGÁLATA A 14-18 ÉVES KOROSZTÁLY KÖRÉBEN}

Annak ellenére, hogy a lisszaboni szerződés tekinthetố a humánerớforrás-fejlesztésen keresztül megvalósuló komplex gazdaságfejlesztés elsố hivatalos okmányának, számos ország már a kilencvenes évek közepén reagált az egyre fokozódó globalizációs versenyképességi kihívásokra. Felismerve a reáltudományokon alapuló kutatás-fejlesztés-innováció $(\mathrm{K}+\mathrm{F}+\mathrm{I})$ kulcsszerepét, jelentốs változásokat indítottak nemzeti szinten Napjaink lattségükel, de a kúćl ettségükkel, de a kuz jztály körében a

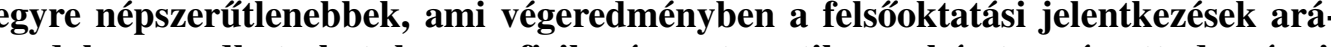
nyát is befolyásolja. Aggodalomra adhat okot, hogy a fizika és matematika - akár természettudományi, akár tanárképzo - szakokon rendkívül csekély a felsooktatási jelentkezési arany, amelynek beláthatatlan következménye lehet a jövó oktatási színvonalára. A Nemzeti Kutatási és Technologiai Hivatal (NKTH) által finanszírozott Csodafa Projekt keretein belül kérdő́ives felmérés segítségével a diákok természettudományos tárgyak (biológia, kémia, fizika, matematika, informatika), valamint a kutatói pálya iránti attitúdjét vizsgálta a szerzó. ${ }^{1}$

Kulcsszavak: kutató, kutatás, pályaválasztás, természettudomány

A lisszaboni stratégiát számos fórumon oktatási vagy kutatás-fejlesztési stratégiaként említik, pedig valójában a Lisszabon-típusú reformok lényege ,,az átfogó célokra alapozott integrált reformstratégia" (Halmai, 2006: p. 1057.), amelynek kétségtelenül egyik kulcstényezóje a humán erơforrás és annak fejlesztése.

A 2002-ben elfogadott állásfoglalás (COM 2003/685, COM 2007/61) már tisztábban mutatja, hogy az oktatásnak nem csupán az iskolarendszerre kell kiterjednie, célja nem kizárólag az ismeretátadás, így az élethoszszig tartó tanulás és az „új alapvetố készségek” fogalmával bóvült az uniós fogalomtár. Ennek keretein be lül fogadta el a Bizottság a tudásalapú társadalomban való élet és munka szempontjából legfontosabb nyolc kompetenciát (1. ábra), amely lehetôvé teszi az egyé számára, hogy megértse és gazdasági szempontbó eredményesen alkalmazza az új technológiákat, maga

szintú ismeretük pedig a $\mathrm{K}+\mathrm{F}$ folyamatokban történố aktív részvételt teszi lehetôvé (PISA, 2006). Mindezek a kompetenciák biztosítják a társadalomban való aktív és produktív részuételt az élethosszig tartó tanulás megvalóstását, végeredményben pedig a váttozálás hoz való alkalmazkớs képessét égéni ́́s nemzeti hoz való alkalmazkodás képességét egyéni és nemzeti

Halmai (2006), Török (2006) és Palánkai (2006) lisszaboni stratégia kapcsán közölt írásai egybehangzóan állapítják meg, hogy a hosszú távú (és fenntartható) növekedés egy meghatározó eleme a humán tốkébe tôrténoo beruházás, amely növeli az alkalmazkodó képességet mind a munkaerốpiac, mind a társadalom változásaival szemben.

Az uniós törekvéseket és a szakértői megállapításokat az a 2006-ban készült PISA- (Programme for International Student Assessment) felmérés is alátá- masztja, amelyben a természettudományos területek a korábbinál hangsúlyosabbak voltak: azok az országok teljesítettek kiemelkedóen, ahol a közoktatás az alapvetố kompetenciákra eredményesebben készítette fel 15 éves korosztályt.

A stratégia megvalósíthatóságával és eredményeivel kapcsolatban azonban nem csupán a fenti szerzó támasztanak kételyt, de a 2006-ban megjelent ajánlás is felhívja a figyelmet arra, hogy a kitúzött célok közül az olvasási, írási és szövegértési képességek enyhe javulása és az oktatásból leszakadók arányának csökjavulása ése valósult meg. Az élethosszig tartó tak csókkentése vaśsut meg. Az élo letve a felnôt épzésben résztvevớk aránya még mindig rendkívül alacsony, és az alacsonyan képze

A tudomány és a társadalom kapcsolatában a kölcsönösség elve, valamint az összhang kialakítása és fenntartása lehet a kulcs, nem csupán a makrogazdaság mutatók értékének javításában, de a komplex nemzeti és uniós célok megvalósításában is. Felvetôdik azonban a kérdés, hogy hol és hogyan lehet elkezdeni a „közös nyelv" kialakítását, melyek az eszközei, illetve gazdaság elvárásaival összhangban mely kombináció hozhatnak már rövid távon kézzelfogható eredményt, és válhatnak hosszú távon fenntarthatóvá A témakör e leszúkített vonatkozásában kétségtelen, hogy az okor tásnak központi szerep juthat ám a mikéntje korántsem ilyen egyszerú.

Az ún. „polgári tudomány” a társadalom széles ré tege számára teszi lehetô̋é, hogy megértse és produktívan hasznosítsa a kutatási eredményekból származó innovatív megoldásokat. A megfelelố nyelvezet használatán túl a polgárok aktivitása, érdeklődése és törôdése szintén a siker fontos összetevốje (Lemke, 1990: p. 78-80; Roth - Barton, 2004: p. 159.).

Breakwell és Beardsell (1992) rámutatott arra, hogy jelentôs eltérés lehet a tudomány oktatási (intézményi) és társadalmi értelmezése között. Míg az oktatás számára a tudás elsősorban leírt, rögzített szabályok átadasát (a köznyelv poroszos oktatúsként emlegeti) és kreasát (a köznyelv poroszos oktatásként emlegeti) és kre tív, szabad alkalmazását (nevezheto ",inn modellnek", a lisszabou addig a tánadalonn dinanikus, a rövid távú változások ra gyorsan reagáló és hosszá távon megbizható tudós közosséget vár. A tudományos oktatás egyik atyján tartott Hurd (in. Roth - Barton, 2004. p. 157.) szerint tudományos múveltségnek összhangban kell lennie tudomány pillanatnyi képével és a társadalomban zaj változásokkal", amely nem csupán a tudomány eredményeinek hasznosulása szempontjából kiemelked fontosságú, de a lisszaboni célkitúzések végső́ eredményét, a gazdasági versenyképességet is befolyásolja.
A hazai és nemzetközi szakirodalom is egyetért abban, hogy a XXI. század természettudományos pedagógiája új kihívásokkal került szembe, és a lisszaboni célok humán erốforrásra vonatkozó részcéljainak eléréséhez radikális változásokra van szükség, mindenekelốtt annak eldöntésére, hogy milyen oktatásra van szükség. Az egyik lehetőség az ún. összevont természettudomány (,science”) tanítása, amellyel szemben leggyakrabban a felsőoktatás számára hiányos lexikális tudást említik. A másik, a gyakran és kiemelkedô eredménnyel alkalmazott (természet)tudományos múveltsé ( scientific literacy") kialátása, amelynek

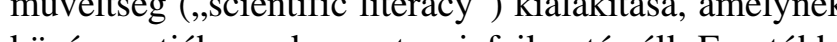
kón irányzat sikere feltehetôn abban âl, hogy rállleszthetố a diszciplináris oktatási tematikára, ugyanakkor megteremti az egyes területek közotti osszhangot, ún. integrált szemléletú (Ádám et al., 2008).

Összefoglalóan: a tudományos múveltség elsajátításának szükségessége három egyéni és két társadalmi vonatkozású okra vezethető vissza:

1) a tudományos múveltség az egyének jellemzője,

2) a tudomány a racionális emberi gondolkodás kialakításának paradigmatikus módja,

3) az iskolai tudás a mindennapi életben alkalmazható (Roth - Barton, 2004: p. 157.)

4) a tudományos technológia megértése elvezet a gazdasági jóléten keresztül a nemzeti biztonsághoz,

5) a tudományos jártasság hozzájárul az etikus attitúd kialakulásához (Bauer, 1994: p. 13-14.)

A tudományos múveltség, mint a természettudományos oktatás újragondolása során - a fenti két vetülete megtartva - a társadalom számára a tudományos múveltség, nem csupán az egyének ismereteinek összege, sokkal inkább azok multiplikatív, kollektív egysége, az egyén számára pedig a döntéshozatal folyamatában egy fontos, de nem egyedüli forrást jelenti (Roth - Barton, 2004: p. 158.)

Ez utóbbi megállapítást támasztja alá a következô kutatási eredmény, amelyet orvostanhallgatók körében végeztek: az „új szemléletứ” orák esetében nem csupán az információszerzés volt kiemelt jellemző, de a problémamegoldó képesség javítása és az együttmúködés (egymástól tanulás) is szignifikáns kapcsolatot mutaott. (Pena - Paco, 2004)

Lemke (1990) gondolata tehát igazolva látszik: ahhoz, hogy ne beilleszkedési problémával küzdő, csupán önállóan dolgozni és gondolkodni tudó „kisakadémikusokat" neveljen az iskola, elengedhetetlen a csoportos munka alkalmazása a tanórákon. Mint a szocializációs folyamat egy iskolai eleme, nem csupán a személyiség 
fejlődését, a feladatok megosztását tanítja meg, de a ri tudomány látható, amely kifejezi egyrészt az iskolai mindennapi élet során is alkalmassá teszi a fiatalokat a problémák felismerésére és megoldására, akár önállóa is. Makroökonómiai szempontból a csoportmunka nem csupán tanári didaktikai módszer és a tanulói fejlesztés egy eszköze, de vállalkozások versenyképességének kulcsa is lehet (2006/962/EK).

A fenti elméletek összefoglalásaként készült az 1 . ábra. Annak ellenére, hogy a lisszaboni stratégia nem különíti el, hogy mely oktatási szintnek mely kompetenciákra kell fókuszálnia, a PISA- és a TIMSS- (Trends in Internations Radnóti, 2004) felméch Radnớt, 2004) felmérések alapján beazonosítható, sá tenni az egyes képességek fejlesztését. Kiemelendô mindemellett, hogy bizonyosak ún. minden szinten fejmindemellett, hogy bizonyosak ún. minden szinten fejBár nem jelöltem, a jobb oldalon található oszlop a hagyományos, középfokú oktatási keretet ábrázolja (jelen esetben a természettudományokra koncentrálva), amelynek megközelítesi módjául szolgálhat mind az integrált szemléletú scientific literacy, mind az ún. öszszevont tudomány. Jelen esetben nem látható kiemelt megkülönböztetés, mert a kutatás kiindulópontja szerint mindkét irányzatnak azonos célt, a kompetenciuk minőségének javítását kell szolgálnia.

A nemzeti tudomány házának tetejét tartó másik oszlopként a korábban más, szintén említett, ún. polgá(i) zépfokú oktatáson túlmutató idốtávot. Az 1. ábra összhangban áll Havas (2009) gondolatával is, amely szerint ,a természettudományi oktatás célcsoportja nem egy szúk elit, a jövố tudósainak privilegizált köre, hanem a társadalom valamennyi polgára életkorra, nemre és társadalmi helyzetre való tekintet nélkül.'”

Az „oktatás házának” négy dimenziója közötti állandó és nélkülözhetetlen interakciót jeleníti meg a középen található négyirányú nyíl, amelynek további iránya lehetne az ipari szektor a gazdaśa és a (z) (oktatás)politika, amelyek a múködési környezetet és a piacot jeponti-

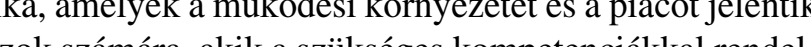

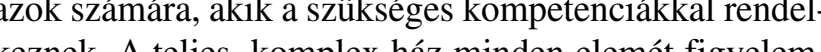
keznek. A teljes, komplex ház ninden elemét figyelembe véve kapcsolódik az oktatási politika és a vonatkozó jogrend altal meghatározott intézmennyi rendszerhez

Az utolsó nyitott kérdés a kutató ismérveinek azonosítása. Véleményünk szerint a kutató az alapkompetenciák magas minőségén túl az átlag feletti kívánesisággal azonosítható, amely az elengedhetetlenül szükséges személyi motivációt biztosítja. A nyitottság szintén fontos adalék, hasznosulása viszont akkor lehet igazán hatékony, ha komplex szemléletmóddal párosul. E két tulajdonság nem csupán a már korábban említet csoport-és projektmunk végzését könnyíti meg sajút méti maját az alkalmazási oldal igényeit is képes befogadni.

A természettudományos tárgyak oktatása során alkalmazott interaktív és szemléltetố eszközök használatának jellemzői

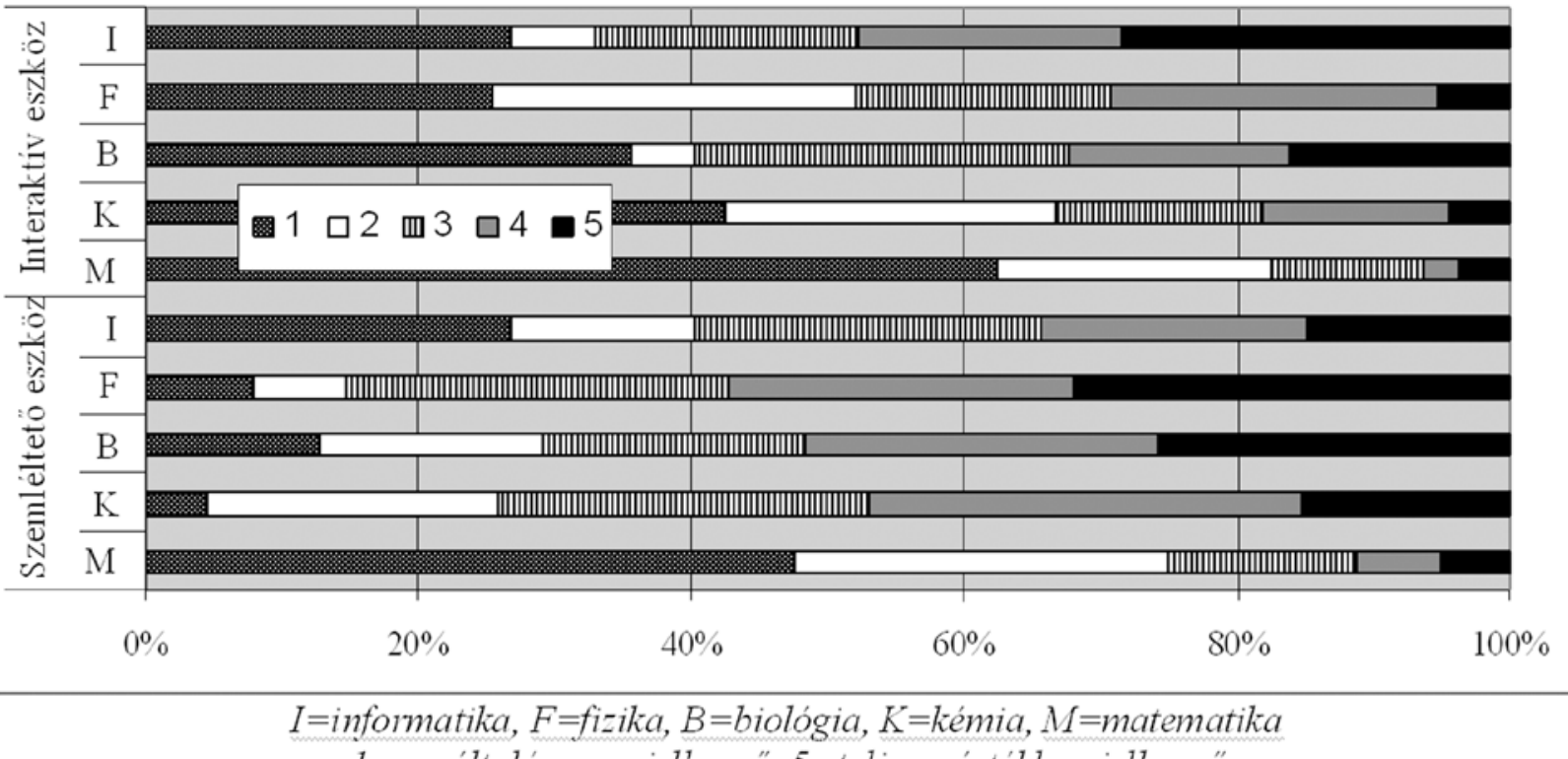

$1=$ egyáltalán nem jellemzó, $5=$ teljes mértékben jellemzó
Ez a típusú megközelítés a hazai oktatási jellemzóket is figyelembe veszi. Az alapfokú oktatási intézményekre jellemzó, hogy a természettudományok alapismereteit (ún. közös fogalomkészletet), alapvetố összefüggéseit próbálja elsajátíttni, annak érdekébe hogy a középszintú oktatásban a jelenségek magyarázatának megértetése lehetségessé váljon, amelyet a már említett nemzetközi felmérések eredményei és Csapó (2005) is alátámasztanak. Problémát jelent azonban, hogy a gondolkodási módot, a vizsgálat szempontjának változtatását ugyanabban a vizsgálati helyzetben nem tanulják meg a diákok.

Szintén jelen munka részét képezte a kutatói pálya iránti attitúd vizsgálata. Gardner (1975 in. Ong Ruthven, 2009) a tudományok iránti diákattitúd ket típusát határozta meg:

a tudomany iranti attitüdöt, amely magába fog-

lalja a tudomány iránti érdeklődést, a tudósok

iránti attitúdöt stb. és

a tudományos attitüdöt, mint nyitottság, objekti-

vitás, őszinteség és szkepticizmus.

Számos tanulmány rámutatott, hogy a diákok pozitív szemléletmódja szoros összefüggésben áll a temészettudományos tároyakban elért eredményekkel (Simon, 1978 in: Adesoji, 2008).

Halladyna és Shanghnessy (1982) a következó, attitüdre ható tényezóket határozta meg:

A természettudományos tárgyak esetében a csoportos munka és a hétköznapi példák jellemzése

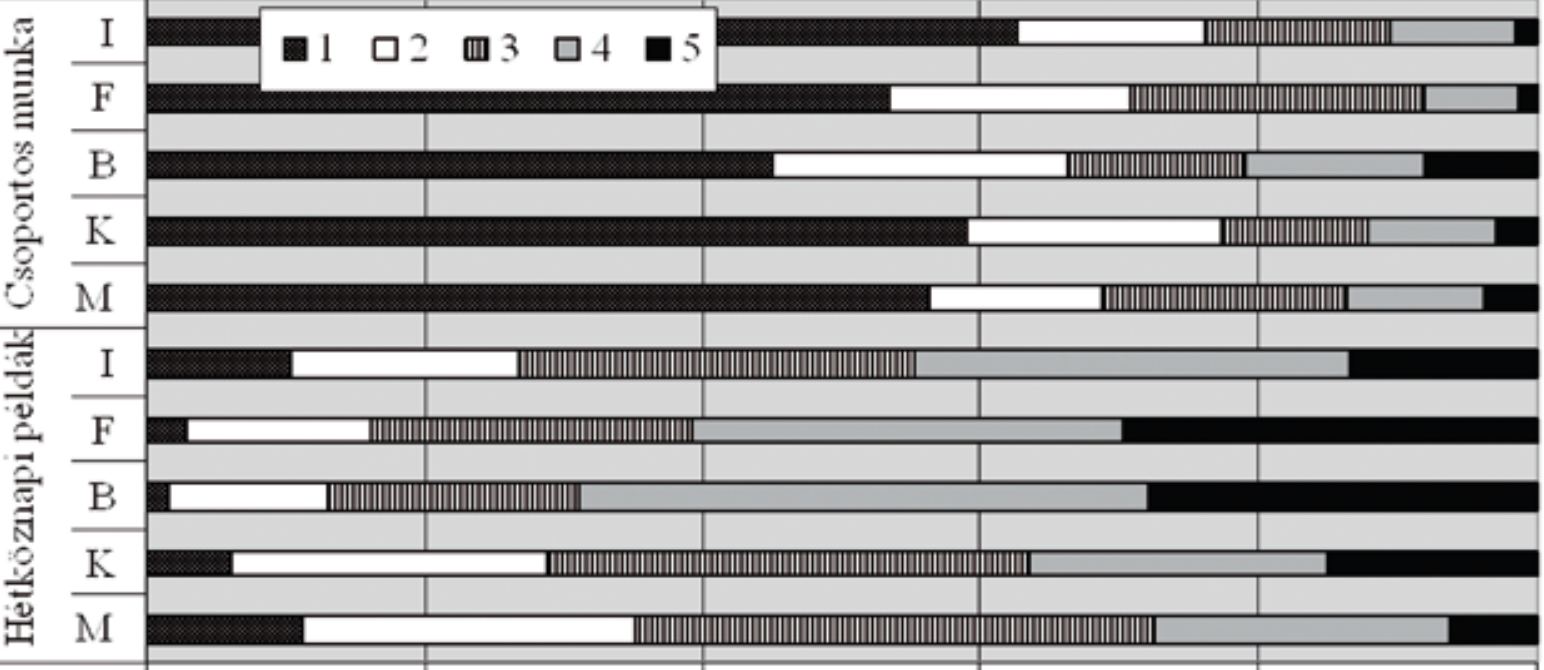

$0 \%$

$20 \%$

$40 \%$

$60 \%$

$80 \%$ $100 \%$

$I=$ informatika, $F=f_{i z i k} a, B=$ biologia, $K=$ kemia,$M=$ matematika

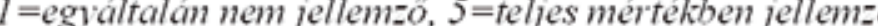

- szülő́i hatás,

a tudós társadalmi megítélése,

Annak ellenére, hogy a tudás nem elegendố a pozitív

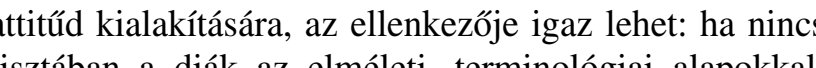
em lesz képes azoknak a készségeknek az elsajátítására, A Az elmúlt évelken számos képség is fejleszthetô. A

A természettudományos tárgyak (a kutatásban rész munka a meghatározó, amely inkább a lexikális tudás atadására, semmint a kulcskompetenciák kialakítására
- tanítási folyama 
A frontális osztálymunka egy másik vetülete: ötfokú skálán értékelve a biológiaoktatás tanulásszervezését a gimnáziumok, szakközépiskolák és szakiskolâk esetében is 4 felett volt az átlagos pontszám, de az orák színesítésére csak elvétve használtak elektronikus premérés szerint megfelelố az eszközellátottság. Nem így a tanulói kísérletek számának növelésére használhatô felszerelés, bár ahogyan a felmérésbő́l olvasható, sajnos a tanári elhatározás is gyakran hiányzik (Franyó, 2003). Renéni tárgyakból a tońri továbbé mín biolo(anári tovabbképzés igeFernengel, 2003). A természettudományos tárgyakkal kapcsolatban a kísérletezés, a jelenségek egyszerúsített bemutatása nélkülözhetetlennek tứnt sokáig, napjainkra azonban jelena tananyag mennyiségére és a csökkenó óraszámra vezethetố vissza, pedig a kísérletek jelentősége kettős: egyrészt változatosabbá teszi az órastruktúrát, másrészt él a azonban az általános két okon az a lehetôség, hogy nem tôvé, de a körülmények és a célok pontos definiálását is. Ezek ismeretében a diákok eredményesebben képes. Ezk - aḱr lexikai szempontból hiónyos - ismen képe-

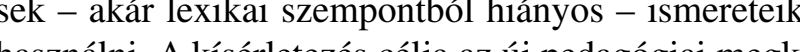
használni. A kisétletezés céja az új pedagógiai megkozelítésben nem csupán a szentéltetés, hanem a tanulók gondolkodásának serkentése, viták, kérdések generála - Ruthven, 2009). Ezt támasztja alá egy korábbi és egy, a közelmúltban végzett kutatás eredménye is, amely szerint a fizikaórákon alkalmazott kíserletek érdekesebbé és érthetóbbe teszik a tananyagot, segítik a tárgy iránti érdeklődés felkeltését (Hadházy - Szabó, 1997, Franyó, 2003; Frenengel, 2003). Még inkább meghat rozó az a ,tudásélmény”, amelyet a diákok akkor élnek sek rámutattak arra hogy az ilyen lehetóségek aránya meglehetósen alocsony. A diákok tudáśt strukturáló, bovít" - án ó azonban nen elegendó a jól bevalt „receptek" szolg követése, tanári magyarázat és instrukció nélkül nem êrik a tapasztalat hasznánató tudássá (Jenkins - Pell, 2006). Gordon Gyớri (2006) egy másik fontos aspektusra mutat rá: „A kommunikációs kompetencia iskol fejlesztése nem csupán egy a sok fontos pedagógiai feladat közül, hanem olyan fejlesztés, amely minden más kompetencia fejlesztésének értékét és érvényét meghatározza." Ez alapján feltételezhetố, hogy amennyiben a diákok megfelelô kompetenciával rendelkeznek e téren, zentációt, segédeszközöket, annak ellenére, hogy a fel2003). Reményre ad okot azonban hogy mind biolotôsen csökkent aránya az órákon belül. Ez többek közö mai fiatal generáció vizuális ,falánkságával”. Túlmuta csupán a folyamat és az eredmény elemzését teszi lehesa (B. Németh, 2002; Nagyné Horváth-Réti, 2008; Ong át, ha a kísérleteket maguk végzik, a korábbi felméré-

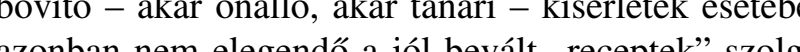

önállóan, az internet segítségével pótolhatják az el nem végzett kísérleteket. Ez azonban a természettudományos tárgyak iranti érdeklódés drasztikus csökkenése miatt aligha valósul meg a hétköznapokban. Felvetódik azonban a kérdés, hogy a természettudományos tárgyak erósíthetik-e egymást. Ahogyan korábban említettem, az egyes területek közötti összhang megteremthetô egyrészt integrált természettudomány oktatásával, másrészt az IKT-eszközök magas szintú használatával. Ez utóbbi azonban jelentôs ellenállást válthat ki, hiszen a korábbi gyakorlat átgondoláśt átdolgoźń́t és a pedagógia szemlélet megújítáśt kívúnja (Kárṕti - Hunya 2009). szz IKT esujujiását ki ánja (Kárpáti - Hunya, 2009). fent fentí kettós jelentóséget kiegészíthetik egy továbbival, cégpedig a sikerélménnyel, amely talán a legfontosabb a természettudományos tárgyak népszerúségének javítása során. A gyakran „,digital native” diákok egy, a számukra biztos területet kapcsolhatnak össze egy gyakran hiányos vagy nem motivált területtel, így a kommunikációs kompetencia fejlesztése hozzájárulhat a természettudományos tudás sikeres elsajátításához.

Jelen munka során a kísérletek szerepe közvetetten jelenik meg egyrészt az osztályzatokra gyakorolt hatásban (amely a tanulási kedv és az érdeklódés erôsségének jelölésére szolgál), másrészt az érdeklődés felkeltésében, amely a kutatás felé történó elkötelezólés egyik fontos összetevőjje.

\section{Módszertan}

A kérdôíves felmérés alapját két kérdőív, közöttük egy, idôs és fiatal kutatókról szóló kisfilm vetítése, valamint a diákokkal folytatott, átlagosan 40 perces mélyinterjú jelentette.

A mintavételezés a Pest megyei középiskolák körébốl származott, a módszertan pedig a társadalomtudományi kutatások során leggyakrabban alkalmazott egyszeri, véletlen kezdôpontú, szisztematikus mintavétel volt. A periodikusságban rejló torzítást elkerülendô, az adatbázisban az iskolák sorrendje random volt (Babbie, 2001: p 226-242). Az iskolán belüli 8 fós csoport ki-

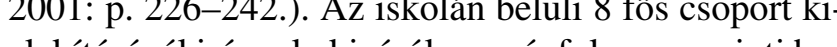
ala moger (minden évfolyamból 2-2 diák), tanulmányi eredmény, érdeklő́dés előzetes felmérése nem Aelt a szempontok között.

A kérdőív kizárólag zárt kérdéseket tartalmazott, válaszadási lehetôség a tesztlekérdezés alkalmával ötszintú Likert-skála, Bogardus-féle társadalmitávolság-skála és szemantikus differenciálskála volt. A zérólekérdezés során tíz diák töltötte ki a kérdôíveket, és a kiértékelés, illetve a személyes megkérdezés alapján megállapítható volt, hogy a Bogardus-féle ská- la szintjei között a 14-18 éves korosztály nem tud értékelhetốen különbséget tenni, ezért ezeket a kérdéseket kether kulonbséget tenni, ezért ezeket a kérdéseket ciálskálának csupán a szélsó értékei maradtak meg. és kizárólag a kutató személyiségi jegyeinek definiálásár szolgált (Babbie, 2001)

Az alkalmazott módszertan közül elsóként a leíró statisztika eszköztárát alkalmaztam: gyakorisáe (módusz), átlag, középérték (medián) és gyakorisági mutatók értelmezése történt (Koop, 2008).

A nem metrikus információk feldolgozása kereszttábla-eleméssel történt, amely a társadalomtudományi kutatások során az egyik leggyakrabban alkalmazott módszertan (Babbie, 2001), míg közgazdasági adatok értelmezésekor hipotézisvizsgálatra szolgál (Ketskeméty - Izsó, 2005: p. 99.) (1. táblázat). 1. táblázat

A struktúravizsgáló módszerek összefoglalása

\begin{tabular}{|c|c|c|c|}
\hline & \multicolumn{2}{|c|}{ Független változó } \\
\hline & & Nem metrikus & Metrikus \\
\hline \multirow{2}{*}{$\begin{array}{l}\text { Függó } \\
\text { változó }\end{array}$} & $\begin{array}{c}\text { Nem } \\
\text { metrikus }\end{array}$ & $\begin{array}{l}\text { Kereszttábla- } \\
\text { elemzés }\end{array}$ & $\begin{array}{c}\text { Diszkriminancia- } \\
\text { elemzés } \\
\end{array}$ \\
\hline & Metrikus & Varianciaelemzés & $\begin{array}{l}\text { Korreláció, } \\
\text { regresszióelemzés }\end{array}$ \\
\hline
\end{tabular}

Sajtos - Mitev, 2004: p.139., 204

A hipotézisek helytállóságának megállapítására a Pearson-féle $\chi 2$ statisztikát, az elvárt értéket, valamin az empirikus szignifikanciaszintet (P-érték) (Szúc 2004: p. 217.; Vincze - Varbanova, 1993) vizsgáltam. Szignifikanciaszintként a szokásosan elfogadott 5\%-o használtam, vagyis az eredmények 95\%-ban megbízhatónak tekinthetók a kapcsolat meglétének vizsgálatakor. A kapcsolat erósségét nominális skálák $2 * 2$-e táblákba történő rendezését követően $\Phi$ együtthato alapján határoztuk meg (Sajtos - Mitev, 2004).

A többváltozós statisztikai módszertanok közül a faktor- és a diszkriminancia-analízis került alkalmazásra. Az elóbbi módszertan a második kérdôív kiértékelését segítette, amelynek célja egyrészt a kisfilm hatásának vizsgálata, másrészt olyan csoportok azonosítása amelyek segíthetik a jövốben a kutatói pálya népszerúsítését. Az egy faktorba tartozó változók megítélésekor sítését. Az egy faktorba

Szúcs (2004) szerint, ha a faktorsúly (a) értéke 0,98 vagy afeletti, akkor igen erôs, 0,86 és 0,98 között erós, 0,7 és 0,86 között közepes, 0,70 alatt nem szignifikáns kapcsolat a jellemzó.

2) Sajtos - Mitev (2004) szerint, azonban a faktor-

súly szignifikanciáját az elemszám is befolyấ- solja, így növekvố n számhoz csökkenô $a$ érték tartozik, jelen esetben 0,60

A diszkriminancia vizsgálata során a nominális függóváltozó (,Vonzónak tartod-e a kutatói pályát?' - igen/nem) és az ötszintú skála segítségével értékelt tantárgyi jellemző́k kategóriákra történô szétválaszthatóságát vizsgáltuk. A szeparálás megfelelősége a Wilks-féle $\lambda$ mutatóval határoztuk meg.

$$
\Lambda=\frac{\operatorname{det}(\underline{\underline{A}})}{\operatorname{det}(A+C)}=\frac{1}{1+\lambda_{1}} ;
$$

(Ketskeméty - Izsó, 2005: p. 201.)

Ha a $\lambda_{1}$ sajátértéke nagy, a $\Lambda$ értéke kicsi lesz, ami csoportok szeparálhatóságának magas fokát jelöli majd. Az elemzés során a kanonikus korreláció értékét is kiszámoltuk, amely azt mutatja meg, hogy a teljes varianciából mekkora részt magyaráz a meghatározot diszkriminancia-függvény. Értéke 0 és 1 közé eshet (Szúcs, 2004)

\section{Eredmények}

A szakirodalmi források alapvetônek tekintik a természettudományos tárgyak iránti attitúd kialakulásában a tantárgyi oktatási folyamatát és a tanári hozzáállást. Ez utóbbi nem volt tárgya a vizsgálatnak, de a hétköznapi példák alkalmazása (3. ábra), illetve a kapott, kedvezó értékek arra engednek következtetni, hogy a vizsgált iskolákban a szaktanárok a tankönyvi tananyagot jelentős mértékben kiegészítik.

Ahogyan a 3. ábrán is látható, a szakirodalmak által kiemelkedôen fontosnak tartott csoportmunka jelenléte elenyésző, legmagasabb arányban a biológiaórákon alkalmazott.

A 4. ábra a két legjellemzóbb figyelemfelkeltési, -fenntartási módok pontszámait jeleníti meg. A szemléltetố eszközök közé tartozott minden kísérletezési, makettbemutatási lehetőség, míg az interaktív eszközök az IKT-berendezéseket jelentették.

A tantárgyak jellemzói és a tárgyakra kapott osztályzatok közötti lehetséges kapcsolat feltárására a korrelációelemzés volt az alkalmas módszertan. A vizsgálat eredményeként sem a p-, sem a t-érték nem igazolta, hogy csoportos munka, a szemléltetố vagy IKT-eszközök használata befolyásolná az osztályzatok színvonalát. Ennek oka feltételezhetôen a számonkérési és felvételi rendszerben rejlik, amely megfelelő ösztönzést ad a jó jegyekhez szükséges otthoni készüléshez. A korrelációelemzés során a p- és t-értékek ugyan nem tették indokolttá a multikollinearitás vizsgálatát, az ellenốrzésként kiszámított korrelációs mátrix megerơsitette ezt a feltételezést.

\section{VEZETÉSTUDOMÁNY}


3. ábra látható, hogy a pályaválasztást a diákok szúk környezete, a családi befolyás, a baráti kör véleménye, és végül az iskolai környezet befolyásolhatja.

A válaszlehetőségek kialakítása leíró statisztikai és kereszttábla-elemzést tett lehetővé, amelynek tároyául a kutatói pályát tárgyául a kutatói pályát vonzonak tartó diákok es: tetói pélát szolgáltó tatoi példát szolgálató személy jelenlete (1),

az iskolarendszeren kivuuli programok látogatása (elsősorban szakkör) (2), - tanulói évfolyam (3) közötti kapcsolatot vizsgáltuk.

Azok közül, akiknek 4. ábra

van információja a kutatói munkáról, 51,4\%ban tartották vonzónak a vizsgált hivatást, míg akire ilyen irányban nem hatnak a közeli ismerốsök csupán 37,8\%-ban, összességében pedig a válaszák 43,8\% a asszességeben pedig a váaszadó $43,8 \%$-a tartja elképközött, közöt, akik kizáták a lehetséges pályák közül a kutatôi lêtet, ötfokozatú Likert-skálán indokolhatta dontésének okát. A legmagasabb átlagértékkel $(3,48)$ jelölt szempont az érdeklődés hiánya volt, a válaszadók 34,6\%-a teljesen egyetértett a felkínált lehetôséggel, a felsố két sáv összevonása már a részvizsgálatba bekerült diákok 60,8\%-át fedi le. Szintén kiemelendő, hogy a megkérdezettek szerint rosszul fizetett és nem megbecsült szakma, és bár mind a mélyinterjú, mind a második kér-

Forrás: Ádám et al., 2008; 12. melléklet $\begin{aligned} & \text { dőív eredménye szerint nem a várható fizetés } \\ & \text { a pályaválasztás szempontja, a kreatív és vál- }\end{aligned}$

Forrás: Ádám et al., 2008; 12. melléklet $\begin{aligned} \text { dôív eredménye szerint nem a várható fizetés } \\ \text { a pályaválasztás szempontja, a kreatív és vál- }\end{aligned}$

\section{Kutatói pálya}

A pályaválasztási attitüd vizsgálatára számos szakirodalmi kutatás eredménye áll rendelkezésre, a lisszaboni strukturális és komplex célok megvalósítása és a kutatás-fejlesztéssel kapcsolatos nemzeti és közösségi makrogazdasági mutatók javulása feltételezi a kutatók számának növekedését. A vizsgálat - a kérdôíves felmérés és a mélyinterjú - során nem volt különbség a természettudományos és a humán irányú kutatás között, első́sorban a kutatói tevékenység iránti érdeklődés, motiváltság állt a középpontban. A szekunder információk alapján tozatos munka lehetôsége nem kompenzálja az elóbbi egatív vonásokat.

A korábban bemutatott tanulmányok szerint a szakkörök szervezése és fenntartása egyre nehezebbé válik, illetve elérhetőségük jellemzóen a tanulmányi versenyektốl függ. Ha csupán a válaszok megoszlását vizsgáljuk, a szakkör látogatása alig 2\%-kal javítja az iskolán kívüli foglalkozást nem látogató 57,6\% vizsgálatában korlátot jelent, hogy a részt vevő iskolák közül hatban szerveznek akár versenyre, akár fel(nem)/42,4\% (igen) arányát. Ennek a hipotézisnek a vételire felkészítő természettudományos tárgyú órát, amelyen a megkérdezett diákoknak csupán 10\%-a vett részt. Az oktatási rendszer egy jelentős, mégis évek, évtizedek óta változatlan jellemzójére mutat rá a tanulmányi versenyen való részvétel motivációjának indoklása: a legmagasabb átlagértékkel a felsőoktatási felvételin elérhetó pluszpontok jellemezhetók, a kategória módusza négyes volt. Annak ellenére, hogy a természettudományos tárgyak népszerúsége hanyatlik, a második átlagértékkel (3,61), az előzôvel azonos, leg gyakrabban előforduló értékeléssel, viszont magasabb gerínal $(3,88)$ a tá gy szeretete lett a köveckasabb mediánnal $(3,88)$ a tárgy

Előzetesen feltetelezheto volt, hogy a fiatalabb dić kok még nen feltere kutáó pályán és ala

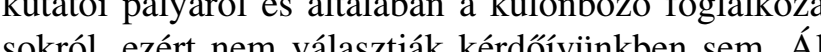
(a talánosságban elmondható, hogy a 9. és 10. évfolyamos diákok közel azonos arányban és meghatározóa „nem”-mel válaszoltak, míg a tizenegyedikeseknél javult a kutatói pályát favorizálók aránya, és szinte azonos értékkel fordult meg a végzősöknél.

A kereszttábla-vizsgálatok eredményét mutatja be a 2. táblázat. A kapcsolat akkor tekinthetô szignifikánsnak, ha a mutató megfigyelt értéke nagyobb, mint elvárt. Látható, hogy

2. táblázat

A kutatói pálya választását ösztönző tényezók hatása

\begin{tabular}{|c|c|c|c|c|c|}
\hline 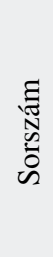 & 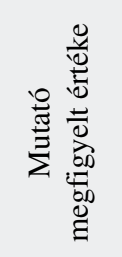 & 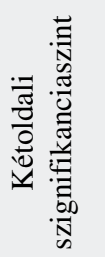 & 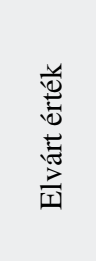 & 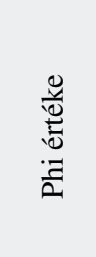 & 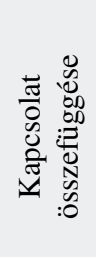 \\
\hline 1 & 1,491 & $>$ & 15,31 & 0,137 & NSZ \\
\hline 2 & 0,04 & $>$ & 14,44 & 0,022 & NSZ \\
\hline 3 & 1,586 & $>$ & 7,88 & 0,141 & NSZ \\
\hline
\end{tabular}

a kétoldali szignifikanciaszint nagyobb

NSZ: nem szigifikáns

Forrás: Saját vizsgálat, 2010

A következók kritérium a kétoldali szignifikanciaszin 0,05-nél kisebb értéke esetén teljesülne, az elóző érték érvényessége mellett. A kapcsolat erôsségét és irány mutató Phi értéke egyik esetben sem közelít egyértemúen 1 felé, vagyis a tényezók között nincsen szignifkáns összefüggés. A mutatók alapján tehát megállapîtható, hogy a környezeti példamutatás, a szakkörökō való részvétel vagy a pályaválasztás közelsége sem osztönzi a kutatói pálya felé fordulás.
Az eredmények láttán tovább folytattam a keresést, és egvizsgáltuk, hogy van-e annak hatása a pályaválasztásra, ha a diákok felkínált tevékenységekból választhatják ki a kutató napi munkáját, illetve feltételeztük, hogy különböző diákkutató versenyek ismerete pozitívan hathat a választásra. A kereszttábla-elemzés második csoportja meglepő eredményt hozott: az egyetlen szignifikáns kapcsolat a „Müvészettörténész, aki megállapította, hogy a Mona Lisa modellje férfi lehetett" lehetôséggel mutatkozott. Ebben a relációban a 2. tábláza minden szempontja teljesiil, a Phi értéke -0,335, vagyis gyenge, de negatív irányú kapcsolat áll fenn.

Szintén a pályaorientáció körénél maradva azt a felevést is górcsó alá vettem, hogy vajon a természettudományos tárgyakból elért kiemelkedó eredmények és az bbő́l adódó szaktanári, családi ösztönzés terelhetik-e a diákokat a kutatói pálya irányába. Az „,igen”-nel válaszolók tanulmányi átlaga nem tekinthetô homogénnek, két csoport kialakítását követôen 56\% átlaga 4,5 alatt, 44\%-a felette volt, amelyből csupán három nem kitünố redményt találtam.

Szakirodalmi háttér és nemzetközi felmérések alapján diszkriminancia-analízis segítségével a következô összefüggések vizsgálata történt meg:

- van-e hatása a diákok osztályzatának arra, hogy vonzó pályaként értékelik a kutatóit, illetve

- a kutatásban vizsgált öt természettudományos tárgy fentebb már ismertetett szempontok alapján történő értékelése ösztönzi-e a kutatói pálya választását.

Az elsố esetben az a feltételezés volt a kiindulópont, hogy a jó osztályzatokkal rendelkezó diákok nagyobb arányban választják a kutatói pályát, mert nem csupán az elméleti tudásuk lehet megfelelóbb, de környezetüktól több bátorítást kaphatnak, illetve a ,jó tanulók” általában több diákversenyen vesznek részt, így a kutatói munkáról elốbb szereznek ismereteket. A diszkriminancia-vizsgálat nem támasztotta alá ezt a feltételezést. Az egyes változókhoz tartozó Wilks' Lambda ́́tćke 0,986-0,998-ig terjedt, ami a Wéc grigificanciaszint jellet kapott 0,303-0,711-ig tejeszignifikanciaszint mellett kapott 0,303-0,711-ig terjetón érteket pedig egyêrtelmû́vé valik, hogy az osztalyzatok és a kutatói pálya értékelése között nincsen különbség. A diszkriminancia-függvény sajátértéke 0,46 volt, a kanonikus korreláció pedig 0,21 , a függvényhez tartozó Wilks' Lambda értéke 0,956 volt, a szignifikancia értéke 0,640. A klasszifikációs táblázat szintén a fenti megállapítást erősíti meg: az első csoportosítási folyamat során az elsố csoportba (,,igen, vonzónak tartom a kutatói pályát") az elemek 48,9\%-a

\section{VEZETÉSTUDOMÁNY}


volt helyesen besorolva, míg az elutasító csoportnál az arány $62,9 \%$ volt, összességében pedig 55\%-ban lehetett helyes a szeparálás. A második, keresztérvényességi vizsgálatnál ezek a mutatók rendre 37,8, 45,7 és 41,3\%-ra csökkentek. Annak ellenére, hogy ez utóbbi esetben jellemzó az alacsonyabb értek, a kiugro êrtékek előfordulásának hiánya miatt (az oszak tekinthető, és megállapítható, hogy a diákok osztályzata jelen vizsgálatban nem gyakorol jelentős hatást a kutatói pálya megítélésére.

A második problémakör eredményeit a 3, táblázat A maso kiemelve a kapcsolat meglétén és. lentóséǵ́n k jellemzéśre haszńlh tó legfon és je lentôségének jellemzésére használható legfontosabb ming tulajdonságai által felvett értékek -tól -ig formában lá

Ahogyan fentebb a módszertani rész is tartalmaz za, a Wilks $\lambda$ minél kisebb értéke jelöli a csoportosíhatóságot, tehát megállapítható, hogy e mutató szerin a vizsgálatba bevont tárgyak nem gyakorolnak hatás arra, hogy valaki vonzónak látja-e a kutatói pályát.

A kutatói pálya megítélésének és

a tárgyak jellemzői közötti kapcsolat legfontosabb mutat

\begin{tabular}{|c|c|c|c|c|c|c|}
\cline { 3 - 6 } \multicolumn{1}{c|}{} & \multirow{2}{*}{ Wilks Lambda } & \multirow{2}{*}{ Szignifikancia } & \multicolumn{2}{c|}{ Diszkriminancia-függvény } & \multicolumn{2}{c|}{ Klasszifikációs táblázat(\%) } \\
\cline { 4 - 7 } \multicolumn{1}{c|}{} & & Sajatérték & $\begin{array}{c}\text { Kanonikus } \\
\text { korreláció }\end{array}$ & Eredeti csoportok & $\begin{array}{c}\text { Keresztér- } \\
\text { vényesség }\end{array}$ \\
\hline M & $0,973-1,000$ & $0,151-0,886$ & 0,058 & 0,235 & 59 & 43,6 \\
\hline K & $0,975-1,000$ & $0,051-0,896$ & 0,109 & 0,314 & 68,7 & 58,2 \\
\hline B & $0,981-0,998$ & $0,289-0,801$ & 0,080 & 0,272 & 60,0 & 41,7 \\
\hline F & $0,881-0,991$ & $0,003-0,431$ & 0,266 & 0,458 & 64,9 & 59,5 \\
\hline I & $0,942-1,000$ & $0,47-0,967$ & 0,144 & 0,355 & 64,7 & 61,8 \\
\hline
\end{tabular}

5\%-os szignifikanciaszintet figyelembe véve, meghatározó elem a kémia és a fizika esetében található. Az elóbbi esetében a szemléltető eszközök használata utóbbinál pedig a hétból öt jellemzố is szignifikáns kapcsolatot mutat: a csoportos munka a kreatív felado kapcheladak a szen.êtcetós ing valami a kellemes hangulú fuggvényt jellemzó két legfontosabb mutató esetében rendkivuúl alacsony sajátêrtekek és a kanonikus korreláció szintên a kapcsolat gyengeségét támasztja alá. $\mathrm{K}$ emelendố, hogy ez utóbbi mutató értéke a fizika tárgy esetében a legmagasabb, $45,8 \%$.

A diszkriminancia-vizsgálat outputjai között legfontosabbnak tartott klasszifikációs táblázatból kiemel két oszlop (első vizsgálat, keresztérvényességi vizsgálat) azt mutatja meg, hogy az egyes változók csoportba

Forrás: Saját vizsgálat, 2010

eszközök használata fordul elố legtöbbször, ezt követi az IKT-eszközök alkalmazása (7), a kreatív feladatok jelenléte (3) és a matematika esetében a hétköznapi pétdák megjelenítése.

A Pearson korrelációs (struktúra) mátrixból faktookként értelmezhetố tényezók olvashatók le (második oszlop, ,Faktorváltozók”), értelmezésük a faktoranalízishez hasonlóan történik. A matematika esetében „,feldat” faktor, a kémia és az informatika esetében „,szemléltetơ”” faktor határozható meg, a fizikához „kísérleti” faktor illeszthetó.

A diszkriminancia-elemzés során általános a centroidok értelmezése, amelyek minden esetben 0 alatti értéket vettek fel, így jelen esetben az elemzéshez többlettartalmat nem adn

VEZETÉSTUDOMÁNY
A második kérdôív kiértékelése faktoranalízissel történt, amelynek elsố lépéseként Kaiser - Mayer Oklin (KMO-) vizsgálat és Bartlett-teszt segítségéve Oklin (KMO-) vizsgálat és Bartlett-teszt segítségév a végrehajthatóságot kellett ellenoorizni, az eredményét az 5. táblázat első sora tartalmazza. Látható, hogy három faktorelemzés készült. Az első esetben az összes változó részt vett a vizsgálatban, a faktorok száma a rendelkezésre álló szakirodalmak ellenére, a tapasztalt eltérések miatt nem került alkalmazásra, Kaiser (a faktor sajátértéke 1-nél legyen nagyobb) és Scree Plot (,könyök ábra”) alapján 9 faktor kialakítása vált lehetségessé (5. ábra).

Az első faktoranalízis Scree Plotja

5. ábra

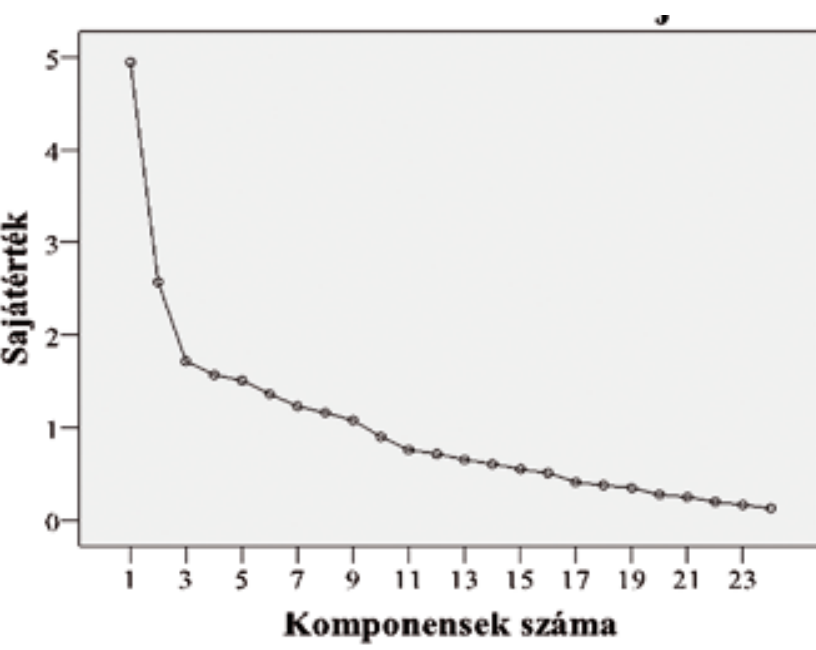

Forrás: Saját vizsgálat, 2010

\begin{tabular}{|c|c|c|c|c|c|c|}
\hline \multirow[t]{2}{*}{ Faktor } & \multicolumn{2}{|c|}{$\begin{array}{c}\text { 1. eset } \\
\text { KMO: 0,618 } \\
\text { Bartlett: szign. }\end{array}$} & \multicolumn{2}{|c|}{$\begin{array}{c}\text { 2. eset } \\
\text { KMO: 0,606 } \\
\text { Bartlett: szign. }\end{array}$} & \multicolumn{2}{|c|}{$\begin{array}{c}\text { 3. eset } \\
\text { KMO: 0,669 } \\
\text { Bartlett: szign. }\end{array}$} \\
\hline & Sajátérték & $\begin{array}{c}\text { Kumulált } \\
\text { variancia (\%) }\end{array}$ & Sajátérték & $\begin{array}{c}\text { Kumulált } \\
\text { variancia (\%) }\end{array}$ & Sajátérték & $\begin{array}{c}\text { Kumulált } \\
\text { variancia }(\%)\end{array}$ \\
\hline 1 & 4,171 & 17,377 & 4,062 & 16,926 & 3,709 & 20,604 \\
\hline 2 & 1,936 & 25,442 & 2,127 & 25,788 & 1,645 & 29,742 \\
\hline 3 & 1,774 & 32,835 & 1,946 & 33,896 & 1,628 & 38,785 \\
\hline 4 & 1,755 & 40,149 & 1,842 & 41,569 & 1,591 & 47,621 \\
\hline 5 & 1,588 & 46,764 & 1,818 & 49,143 & 1,392 & 55,353 \\
\hline 6 & 1,560 & 53,266 & 1,609 & 55,848 & 1,306 & 62,610 \\
\hline 7 & 1,504 & 59,534 & 1,364 & 61,531 & 1,242 & 69,508 \\
\hline 8 & 1,436 & 65,518 & & & & \\
\hline 9 & 1,419 & 71,431 & & & & \\
\hline
\end{tabular}

szign.= szignifikáns

\section{VEZETÉSTUDOMÁNY}

XLII. ÉVF. 2011. 12. SZÁM / ISSN 0133-0179

Az 5. táblázat értékei a varimax rotációval előállíkumulált varianciát kiemelve.

Az első vizsgálat eredményeként kapott faktorok oozưl négybe csupán 1-1 elem került, ezért a változók számának további redukálása érdekében a számítás megismétlése torrtent. Ennek során a faktorok számát kumulált $71,4 \%$-os variancia várhatóan még így is $60 \%$ felett lesz, így ugyan elveszhet az információk közel 10\%-a, de a kapott hipotetikus változók jobban értelzhetóvé válhatnak.

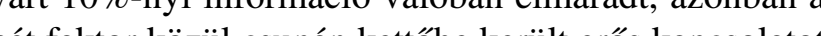
mutató, illetve a hatodik faktor esetében még két, 0,50 Körüli faktorsúllyal rendelkező változó

A harmadik vizsgálat során (3. eset) az elsô vizsgáatban a 0,60 alatti faktorsúllyal rendelkezó hat változot kihagytam, de más megkötés (pl. faktorszám) nem

pitható hogy a vizsólála két oszlopa alapján megállaszerint javultak. A KMO értéke nőtt, a Bartlett-tesz szignifikáns kapcsolatot mutat, a faktorok száma crökkent, így pontosabb meghatározás lehetséges, a kumulált variancia tekintetében pedig csupán két százalékos eszteség történt.

Az elvégzett vizsgálatok alapján a harmadik faktornalízis eredménye a leginkább elfogadható, így a faktorok elnevezése ennek figyelembevételével történt.

5. táblázat 
A 6. táblázat minden vizsgálat faktorához tartozó kérdéssorszámot tartalmazza, amelynek célja a közö pontok (vastagítva) ábrázolása volt. A faktorsorszán ban ugyan látható eltérés, tartalmilag azonban az értemezést nem befolyásolja.

6. táblázat

A faktorok tartalma (kérdések száma)

\begin{tabular}{|c|l|l|l|}
\hline Faktor & \multicolumn{1}{|c|}{$\mathbf{1 .}$ eset } & \multicolumn{1}{c|}{$\mathbf{2 .}$ eset } & \multicolumn{1}{c|}{ 3. eset } \\
\hline 1 & $\mathbf{2 , 3 , 4 , 5 , 6 , 2 0}$ & $\mathbf{2 , 3 , 4 , 5 , 6 , 2 0 , 9}$ & $\mathbf{2 , 3 , 4 , 5 , 6 , 2 0}$ \\
\hline 2 & $\mathbf{1 4 , 1 5}$ & $18,16,1$ & $\mathbf{1 4 , 1 5 , 1 9}$ \\
\hline 3 & $\mathbf{1 2 , 1 3}$ & $\mathbf{1 2 , 1 3 , 2 2}$ & 18,8 \\
\hline 4 & 18,19 & $\mathbf{1 4 , 1 5 , 1 9}$ & $\mathbf{1 2 , 1 3}$ \\
\hline 5 & $\mathbf{1 , 1 0}$ & $11,8,24$ & $\mathbf{7}$ \\
\hline 6 & $\mathbf{7}$ & $\mathbf{7 , 2 1}$ & $\mathbf{1 , 1 0}$ \\
\hline 7 & 8 & $\mathbf{2 3}$ & $\mathbf{2 3}$ \\
\hline 8 & 17 & & \\
\hline 9 & $\mathbf{2 3}$ & & \\
\hline
\end{tabular}

Forrás: Saját vizsgálat, 2010

Látható, hogy az elsố faktor tartalma mindhárom vizsgálat esetében azonos, illetve 0,533-as faktorsúllya kiegészül a kilences kérdéssel. A 14 és 15 . számú kérdés minden alkalommal egy változóba került, az utolsó két esetben azonban a 19. kérdés is bekapcsolódott, így a tartalmi definiálásnál a háromtagú változat let figyelembe véve. Abban az esetben, amikor a változók összecsoportosításában jelentôs eltérés mutatkozott, az értelmezési sorrend a magasabb KMO-érték alapján a következô volt: kiinduló pontot a 3. eset, segítséget az 1. eset, pontosítást a 2. eset jelentett. Ezek alapión következó faktoroknevek alakíthatók ki

- Kutatópalánta (2, 3, 4, 5, 6, 20): A faktor elnevezése azokból a változókból adódik, amelyek nem csupán a lelkesedést, a kutatásban rejló szépségek iránti fogékonyságot, de a tenni akarást is mutatják (.,Kedvet kaptam a kutatáshoz", „Kedvet kaptam ahhoz, hogy kapcsolódjak egy "szakkörhöz").

Az emberközzliként $(14,15,19)$ definiált csoport esetében a - külsố és belsố - emberi tulajdonságoké a főszerep, ezek alapján dönthetó el, a csoporthoz tartozás hajlandósága. Amennyiben azonosulni tud valaki a megismert vonásokkal,

azonosulni tud valaki a megismert

Presztízsorientált $\left(12^{2}, 13^{3}, 22\right.$,) attitúd esetén nem a munka milyensége, sokkal inkább a társadalmi és szakmán belüli megítelés, és nem utolsósorban a „boldogulás” mikéntje a lényeges. Annak ellenére, hogy a kérdések látszólag ellentmonda- nak, a megfogalmazás minimális eltérése rámutat a kulcspontra: az elismerés és a ranglétrán való elơrejutás nem azonos, és nem feltétlenül van okokozati kapcsola

- Egyfókuszúnak (23) tekinthetók azok a diákok, akiknek feltehetốen kialakult és szilárd véleményük van a kutatói pályával kapcsolatban, ez pedig - a kérdőív alapján - a reál területekre korlátozódik.

- A tudás- vagy ismeretorientált $(1,10)$ csoport hasonló a kutatópalántához, de hiányzik belóle a tentroytól fïggetlen, althe de halkesect és aklelkesedés és aktivitás.

- Az önmegvalósitók (7,21) számára a viszonyítási pont nem kívülról, a társadalomból (presztízsorientált) vagy egy idealisztikus képból (emberközeli) adódik, sokkal inkább abból a belső preferenciaskálából, amely kialakításában a szúkebb környezetnek lehet kulcsszerepe. Ezek a diákok választják feltételezhetóen szüleik, nagyszüleik foglalkozását.

- Informálatlan, bizonytalan $(18,8)$ faktor olyan attitúdöt takar, amelynek szemléletmódjából hiányzik a komplexitás, nem tud vagy - a könynyebb utat választva - nem akar nyitni korábbi véleményéhez képest.

\section{Összefoglalás}

A Tanács európai referenciaértékként 15\%-os növekedést határozott meg a matematika, a természet- és múszaki tudományok terén végzettséggel rendelkezók számában. 2010-ben a múszaki és természettudományos nappali alapképzésre jelentkezók létszámát tekintve a 2. (11.717) és a 10. (3.208) helyre kerültek.

A felvi.hu adatai szerint a matematika, fizika, kémia népszerúségében is határozott javulás következett be.

A lisszaboni stratégia megvalósításával kapcsolatban számos, fentebb említett szerzô rámutatott, hogy addig, amíg a változás elsődleges feltételeként forrásbővitést határoznak meg és nem a struként a

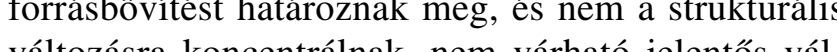
tozás. A szakirodalmi háttér bemutatta és a kutatási eredmények igazolták, hogy a természettudományos tárgyak oktatása során ritkán alkalmazott a frontális munkátó eltéró módszertan. Ennek oka a szakmai felkészültség hiányosságaiban keresendốk. Korábbi vizsgálatok szerint a tanulási hajlandóság akár az IKT-eszközök használatát, akár az óralátogatást tekintve jelentôs, korlátot jelenthet azonban a részvétel eltérő mértékú és struktúrájú finanszírozása.
A vizsgált természettudományos tárgyak oktatásában kulcsszerep juthat az IKT-eszközök használatának Nem csupán a léró statisztikák tükrözik, de a mélyinterjúk során is többször elhangzott, hogy a tanárok ritká és bizonytalanul használják az információtechnológi berendezéseket. Fontos lenne, hogy a 14-18 éves diákok információéhségét szövetségesként fogadják, és az eszközök segítségével minél több érzékszervet kössenek le, behozva a külvilágot az iskola falai közé. Szintén lehetôvé válna az azonnali megerősítés, végeredménybe pedig nem csupán a kettôs tudás", de a hétköznapi tá-

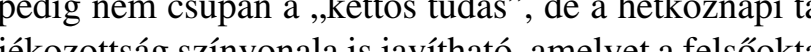
tási intézmények is egyre inkább elvárnak.

A pedagógusok készségeinek fejlesztése a differenciált oktatás irányába mutató folyamatot is elindíthatná, amely alapvetố feltétele a faktorelemzésben meghatározott csoportok eltéró szükségleteinek kielégítéséhez.

A magyar szakirodalmak alapján elmondható, hogy a Halladyna és Shanghnessy (1982 in: Adesoji, 2008) által meghatározott faktorok közül a tanítási folyamato alapvetően határozza meg a tanári attitúd, a kettő nem választható szét. Ennek a kutatásnak ugyan nem volt célja a diákok nemének vizsgálatba történó bevonása, sem a kor, sem a szülôii hatás nem mutatott egyértelmû́ összefüggést a kutatói pálya választásával. Szintén a szakirodalmi háttérre és a korrelációs vizsgálatok eredményére támaszkodva állapítható meg, hogy a tudo-

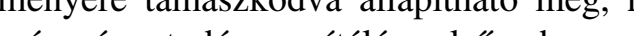
mány és a tudôs negítelése elsósorban a kutatói pálya válaszlását hatarozza meg, a tárgy iránti attitúdre nincsen közvetlen hatással. Feltételezhetô, hogy ennek oka a számonkérés módjâval és a felvételi pontok számításával áll elsősorban kapcsolatban (erre utalnak a szakkörön való részvétel indoklására adott pontszámok is)

$\mathrm{Az}$ angol ROSE-projekt részét képező „Véleményem a tudományról és a technológiáról" kérdésre adott válaszok szerint a tudomány képes legyőzni a betegségeket, kényelmesebbé és egészségesebbé tenn a hétköznapokat, jobb lehetôségeket biztosítani a jövő nemzedékének, ám meglehetôsen szkeptikus a környezetvédelem és a szegénység problémáinak megoldás tekintetében. Ezt kiegészítve azzal a jelen kutatás kiértékelése és a mólyinterjú són tapen kutatás ki-

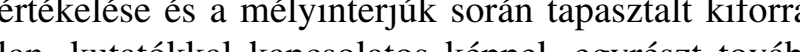
lan, kutatókkal kapesolatos képpel, egyrészt továb igazoläst nyen, hogy a kutatói szegmens és az iskol kölcsōnōsen szeparalt, nem kizárolag az egymáss folytatott kommunikáció hiányzik, de az iskolák zártságát is növeli.

Javaslatként megfogalmazható, hogy a változást három irányból indítsák:

1) Az állami finanszírozás strukturális alakítása, az intézményi rendszer megfeleltetése a feladatoknak (és nem fordítva).
2) A természettudományos tárgyak jelentőségének tudatosítása iskolán belül tantestületi, tanulói és zü̈lói szinten egyarán

3) A kutatói pálya presztízsének javítása különbözó kommunikációs eszközök segítségével, a társadalmi elfogadás és megbecsülés javítása. E folyamat egyik kulcsa lehet, hogy ne kizárólag a tárgyak fontosságára, hanem a tudás révén elérhetố eredmények népszerüsítésére koncentráljanak.

\section{Lábjegyzet}

Közzönetnyilvánítás: Jelen publikáció az NKTH által finanszírozott INNOTARS 08 programon belül támogatott Csodafa Projekt keretein belul készult.

munkájuk elismerése objektív, kevésbe zár a kutá́k eredmén

gekre a többi szakmához hasoknlóvek, kapcsolatokra, ismeretsétáshoz

\section{Felhasznált irodalom}

Ádám P. - Baranyai J. - Bán S. - Csorba L. - Kertész J. - Radnóti K. - Szalay L. (szerk.) (2008): A természettudományos közoktatás helyzete Magyarországon. Az OKNT-bizottság jelentése I., Budapest. Letöltés dátuma: 2010. március 10.; Jelentés: http://www.phy.bme. hu/ termtud/OKNT_tanulmany_I.pdf; Melléklet: http:// www.phy.bme.hu/ -termtud/mellekletek_szept_26.pdf Babbie, E. (2001): A társadalomtudományi kutatás gyakorlata. Balassi Kiadó, Budapest, p. 190-200.; 226-242.; $454-474$

Baráth Cs.né - Ittzés A. - Ugrósdy Gy. (1996): Biometria. Mezőgazda Kiadó, Budapest

Bauer, H.H. (1994): Scientific Literacy and the Myth of the Scientific Method. University of Illinois Press, Chicago, p. $12-13$

Breakwell - Beardsell (1992): Students' attitudes to science and technology. Letöltés ideje: 2010. május 5.

http://www.ils.uio.no/english/rose/network/countries/ sweden/swe-jidesjoe-ioste2004.pdf

B. Németh M. (2002): Iskolai és hasznosítható tudás: a természettudományos ismeretek alkalmazása. In: Csapó B. (szerk.) Az iskolai tudás. Osiris Kiadó, Budapest, p. 126.

OM (2003): 685: Oktatás és képzés 2010: A Lisszaboni Stratégia sikere a sürgós reformokon múlik.

COM (2007): 61: Az oktatásra és képzésre vonatkozó liszszaboni célkitúzések tekintetében elért haladás nyomon követésére szolgáló mutatók és referenciaértékek összefüggó keretrendszere

Csapó B. (2003): Oktatás az informaciós társadalom számára. Magyar Tudomány, 2003/12., p. 1478-1785. 
Csapó B. (2005): Tanuló társadalom és tudásalapú oktatási rendszer. In: Komlóssy Á. (szerk.) (2005): Ismeretek és képességfejlesztés. A 42. Szegedi Nyári Egyetem Évkönyve. Tudományos Ismeretterjesztô Társulat, Szeged, p. 5-21.

Európai Unió (2009): Progress Towards The Lisbon Objectives In Education And Training - Indicators and benchmarks 2009. Letöltés ideje: 2010. június 25 . http://ec.europa.eu/education/lifelong-learning-policy/ doc/report09/report_en.pdf

Fernengel A. (2003): Kémiatanítás a középiskolában A 2003-as obszervációs felmérés tapasztalatai. Letöltés ideje: 2010. június 20.; http://www.oki.hu/ oldal.php?tipus=cikk\&kod=kozepfoku-FernengelKemiatanitas

Franyó I. (2003): Biológiatanítás a középiskolában - A 2003as obszervációs felmérés tapasztalatai. Letöltés ideje: 2010. június 20.; http://www.ofi.hu/tudastar/tantargyakhelyzete/biologiatanitas

Gardner (1973): The Impact of ScienceWare and Foundations on Students' Attitudes Towards Science and Science Classes. Journal of Science Education and Technology. 5, 1, p. 59-67.

Gordon Gyóri J. (2006): A kommunikációs kompetencia fejlesztése az iskolában. in: Kerber Z. (szerk.): Hidak a tantárgyak között. Országos Közoktatási Intézet, Budapest. p. 78 .

Hadházy T. - Szabó Á.: Gimnáziumi tanulók véleménye a fizikaoktatásról. Fizikai Szemle 1997/9.

Halladyna - Shanghnessy (1982): Attitudes towards science: A qualitative synthesis. Journal of Research in Science Teaching, 66, 4, p. 547-563. in: Adesoji, F. A. (2008): Managing Student's attitude towards Science through Problem - Solving Instructional Strategy. Anthropologist, 10(1), p. 21-24.

Halmai P. (2006): Quo vadis, Európa? Európa esélye: a Lisszaboni Stratégia. Magyar Tudomány, 2006/9, p. 1057-1069.

Havas, P. (2009) A természettudományi kompetenciákról és a természettudományi oktatás kompetencia alapú fejlesztésérôl. Letöltés ideje: 2010. május 20.; Letöltés helye: http://www.ofi.hu/tudastar/hazai-fejlesztesi/ havas-peter

Jenkins, E.W. - Pell, RG. (2006): The relevance of Science Education Project (ROSE) in England: a summary of findings. p. 39-50. Letöltés ideje: 2010. május 20. http://www.ils.uio.no/english/rose/network/countries/ uk-england/rose-report-eng.pdf

Kárpáti A. - Hunya M. (2009): Kísérlet a tanárok IKTkompetenciája közös európai referenciakeretének kialakítására - a U-Teacher Projekt II.

Ketskeméty L. - Izsó L. (2005): Bevezetés az SPSS programrendszerbe. ELTE Eötvös Kiadó, Budapest; p. 99-111, 201.

Koop, G. (2008): Közgazdasági adatok elemzése. Osiris, Budapest. p. $38-48$.
Lemke, J.L. (1990): Talking Science: language, learning and values. Ablex Publishing, Westport, p. 78-80.

Nagyné Horváth E. - Réti M. (2008): A kémia tanítása során alkalmazott módszerek és szemléltetési módok. In.: Ádám P. - Baranyai J. - Bán S. - Csorba L. - Kertész J. - Radnóti K. - Szalay L. (szerk.) (2008): A természettudományos közoktatás helyzete Magyarországon. Az OKNT-bizottság jelentése I., Budapest. Letöltés dátuma: 2010. március 10.; Melléklet: http://www.phy.bme. hu/ termtud/mellekletek_szept_26.pdf; p. 112-122.

Ong, E.T. - Ruthven, K. (2009): The Effectiveness of Smart Schooling on Students' Attitudes Towards Science. Eurasia Jurnal of Mathematics, Science and Technology Education, 5/1, p. 35-45.

Palánkai T. (2006): Quo vadis, Európa? A Lisszaboni Program megvalósíthatósága. Magyar Tudomány, 2006/9., p. 1045-56.

Pena, A. - Paco, O. (2004): Attitudes and Views of Medical Students toward Science and Pseudoscience. Med Educ Online 2004; 9:4

PISA, 2006; Balázsi, I. - Ostorics, L. - Szalay, B. (2007): PISA 2006 Összefoglaló jelentés - A ma oktatása és a jövô társadalma. Oktatási Hivatal, Budapest

Radnóti K. (2004): Gyenge kezdés után erôs visszaesés avagy miért nem szeretik a diákok a fizikát? Iskolakultúra, XIV/január, p. 50-69.

Roth, W.-M. - Barton, A.C. (2004): Rethinking Scientific Literacy. RoutledgeFalmer, London, p. 157-159.

Sajtos L. - Mitev A. (2004): SPSS kutatási és adatelemzési kézikönyv. Alinea Kiadó, Budapest, p. 139., 204.

Simpson R.D. - Wasik, J.L. (1978): Correlation of selected affective behaviours with cognitive performance in a biology course for elementary teachers. Journal of Research in Science Teaching, 15, 1, p. 65-71. In: Adesoji, F.A. (2008): Managing Student's attitude towards Science through Problem - Solving Instructional Strategy. Anthropologist, 10(1) p. 21-24.

Szúcs I. (szerk.) (2004): Alkalmazott statisztika. Agroinform Kiadó, Budapest, p. 217, 253-254., 477-496.

Török Á. (2006): Quo vadis, Európa? A Lisszaboni Stratégia értelméról és tanulságairól 2006 tavaszán

Vincze I. - Varbanova, M. (1993): Nemparaméteres matematikai statisztika. Akadémiai Kiadó, Budapest, p. 77-79.

2006/962/EK, Az Európai Parlament és a Tanács ajánlása az egész életen át tartó tanuláshoz szükséges kulcskompetenciákról.; http://www.felvi.hu/felveteli/ ponthatarok_rangsorok/jelentkezok_es_felvettek/szakos_elemzes_elozetes; Letöltés ideje: 2010. június 25 .

Cikk beérkezett: 2010.8 . hó

Lektori vélemény alapján véglegesítve: 2010.11 . hó 